Article

\title{
The Authenticity of Myriad Things in the Zhuangzi
}

\author{
Chiayu Hsu \\ Department of Philosophy, Peking University, Beijing 100871, China; cyhsu@pku.edu.cn
}

Received: 14 February 2019; Accepted: 7 March 2019; Published: 21 March 2019

Abstract: A large quantity of past research in philosophical Daoism has been dedicated to the authenticity of “dao"; this essay shifts the focus to the authenticity of the "myriad things 萬 物 (wanwu)" in the Zhuangzi. The concept of “myriad things", which later gains paradigmatic importance in Chinese philosophy, was first introduced in the Laozi and developed in the Zhuangzi. Under the collective heading of "myriad” , "myriad things” encompasses all of the variegated existing entities in the empirical world, while also taking into account the individual particularities of each entity without calling forth any singular or set of qualities, or "essence" , that is shared by all individuals. As a concept that safeguards individual particularities, the use of "myriad things" in the Zhuangzi serves to counterargue against the essentialist tendency to treat "humans 人 (ren)" as a collective of moral agents with a singular and identifiable moral essence. By the same token, Daoist thinkers re-interpret the meaning of "heaven 天 (tian)" with "the collective name of the myriad things 萬物之總名”, thus transferring the transcendent meaning belonging to the former as a transcendent moral authority to the myriad variegated principles that are inherent to each existing and transforming individual. The Daoist theoretical frame breaks away from that of "heaven-human" and connects the re-interpreted "heaven" with concepts of "self-so/self-affirm 自然 (ziran)”, “essentials 情 (qing)”, “nature 性 (xing)”, and “potency 德 (de)”. In this respect, “authenticity 真 (zhen)”, as it is warranted by “non-action 無為 (wuwei)”, is proposed as an ultimate state of attainment that is identified with the self-realization of each individual being as herself, over and above the so-called moral goodness and its opposite. Furthermore, the self-realization of the authenticity of the myriad things is seemingly paradoxical in the sense that, from the perspective of the “transformation of the myriad things 萬物之化” , the separation between object and subject both exists and is non-existent. The proposition of "myriad things" opposes the essentialization of human beings, whereas the doctrine of the transformation of the myriad things opposes the belief in fixed essentials in individual entities. The road to realizing "authenticity" as herself is thus a never-ending process for each individual member of the myriad things.

Keywords: myriad things; essentials; transformation; ziran; nature; heaven

\section{The Earliest Uses and Meaning of "Myriad Things" and Its Significance in Daoist Philosophy}

Few scholars would contest the centrality and profundity of "dao" in philosophical Daoism, but equally few have made clear that it is the discussion surrounding the concept of "myriad things 
萬物 (wanwu)” that marks the distinguishing feature of Daoist thought. ${ }^{1}$ For it is no secret that all thinkers in the pre-Qin period invoked the idea of "dao" in one way or the other. Before explicating why the concept of "myriad things (wanwu)" is an indispensable concept for the Daoist philosophy, I will first point out that the earliest philosophical uses of "myriad things" - a term that had undoubtedly developed into a key concept in the Chinese philosophical paradigms-are first found in Daoist texts.

The earliest extant instance of "myriad things" is found in the Guodian bamboo-slip (Guodian A

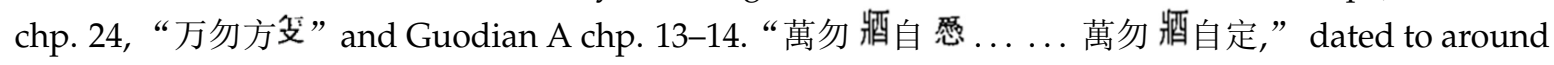
341-00 BCE). ${ }^{2}$ The term "myriad things" is featured as many as 20 times in the Laozi alone, whereas uses of the term in other pre-Qin canonical texts are very limited, devoid of philosophical significance, and could be fraudulent additions by later writers. ${ }^{3}$ In contrast, in Confucian texts, the Analects has one instance of “hundreds of things 百物 (bai wu)", whereas the Mencius, an author contemporary to Zhuangzi, features merely one instance of "myriad things" . This serves to demonstrate that “myriad things” does not constitute a key concern for Confucius and Mencius.

The Zhuangzi, on the other hand, includes 102 instances of “myriad things萬物 (wanwu)”. More specifically, uses in the inner chapters are usually connected to concepts of "one - (yi)" or "transformation 化 (hua)." ${ }^{4}$ Examples in the inner chapters include, "Combine the myriad things and make them into one 旁礴萬物以為一” (ICS Zhuangzi 1/2/19-20), “"the myriad things and I are one 萬物與我為一” (ICS Zhuangzi 2/5/21-22), “the transformations of myriad things 萬物 之化” (ICS Zhuangzi 4/10/8), “the myriad things are all one 萬物皆一” (ICS Zhuangzi 5/3/14), and “his riches are loaned to the myriad things and makes them transformed [明王] 化貸萬物” (ICS

1 Sarah Allan (Allan 1997, p. 96) translated “wanwu” into “myriad living things”. She rightly pointed out that wu in the ancient Chinese contexts refers not merely to living things but also non-living entities. "Things" , on the other hand, refers primarily to non-living objects in English, and therefore would not be a suitable translation of " $w u$ ”. Thomas Michael also noticed that "things" in English are primarily inanimate objects, while "wu" refers to both animate and inanimate objects. Considering that the myriad wu are conventionally described as "generated” or "living 生 (sheng)" , he keeps in line with Allan and translated $w u$ as "living things" (Michael 2015, p. 271). Nonetheless, regarding Zhuangzi, 19 defined, “Whatever has forms, images, sound, and color, is a thing. 凡有貌象聲色者皆物也”. That “things物 (wu)” refers to all existing entities, anything with perceptible qualities can be identified as a "thing 物 (wu)” ; therefore, I still opt to translate "wanwu" as "myriad things".

2 The tomb Guodian texts here refers to the comparing table of the full text from nine versions of the Laozi, edit. The Institute for Excavated Documents of Peking University (2012) 北京大學出土文獻研究所編, Beijingdaxue cang xihan $z h u s h u$ vol. 2 《北京大學藏西漢竹書 [負]》. Shanghai: Shanghai guji chubanshe. (pp. 197, 205).

3 The term “myriad things” is not found in The Book of Songs 《詩經》, Rites of Zhou 《周禮》, Rites and Rituals 《儀禮》, The Book of Chang 《易經》, or Spring and Autumn 《春秋》, including its three annotations. It is found in Shang Shu 《尚書》, but only in the pseudo-ancient chapter “Great Declaration泰誓(Tai shi)" ( "Heaven and earth is the parent of myriad things; and of myriad things, human is the most highly endowed.” ) It also appears once in the Yue Yu Xia 越語下 of the Guo Yu《國語》( “Only the earth can enshroud the myriad things into one. Its principle is not ineffectual. Issuing myriad things, including farm animals and wild animals, it then enjoys the resulting repute and benefit.” )

4 There has been an ongoing debate regarding the dating, the authorship, and the compilation of the Zhuangzi, as well as the division of "inner", "outer”, and “miscellaneous” chapters. Scholarship usually takes a certain way of reading the complex text attributed to the historical Zhuang Zhou (Zhuangzi), and has a general consent that the inner chapters represent the authentic core of the thought of the historical Zhuangzi, whereas outer and miscellaneous chapters are later works written by followers of the original author. Chapters are divided into different categories by an editor according to their various theses. It is ascertained that the Zhuangzi as seen today is the editorial product of Guo Xiang (?-312 CE), who made substantial changes to more archaic versions of the text, which are not accessible to us anymore. Angus C. Graham (Graham 1986, pp. 283-31), Liu Xiaogan (Liu 2010), and David McCraw (McCraw 2010) provided critical analyses of the Zhuangzi' s central thesis, with reference to the Zhuangzi' s grammatical features, imagery, theme, conceptual words and phrases, and phonetics. This paper maintains that the Zhuangzi is more like an archive with the chapters as texts that have "family resemblance" to some relative subjects. Therefore, Zhuangzi chapters that are acknowledged as not belonging to the line of Zhuangzi can still be referred to in a discussion of the Zhuangzi' s philosophy.

5 The original Chinese text of the Zhuangzi used for this study refers to A Concordance to the Zhuangzi (Zhuangzi zhuzi suoyin 《莊子逐字索引》), ed. D.C. Lau, Ho Che Wah and Chen Fong Ching. ICS (the Institute of Chinese Studies) series 43. Hong Kong: Commercial Press, 2000. The numbers of the reference indicate the “chapter/page/line” in sequence. 
Zhuangzi 7/20/22). In the outer and miscellaneous chapters, discussions on the "myriad things" involved in more comprehensive inquiries into the origin and the conditions of the existence of all things in the universe. Instances include "the commencing of the production of myriad things 萬物之 所生” (ICS Zhuangzi 25/76/15), “dao is the course by which the myriad things should proceed道 者萬物之所出” (ICS Zhuangzi 31/94/27), “the different essentials of myriad things萬物之情” (ICS Zhuangzi 20/53/15), “the principle pervading the myriad things 萬物之理” (ICS Zhuangzi 17/45/10), and "from the conjunction of their [the Heaven and the Earth] non-action, the myriad things are brought forth 兩無為相合萬物皆化” (ICS Zhuangzi 18/48/5). The Zhuangzi 25 is self-conscious in acknowledging the "myriad things" to be an intellectual jargon when it states, "When we speak of them as 'the myriad things,' we simply use that large number by way of accommodation to denominate them. 曰萬物者, 以數之多者號而讀之也” (ICS Zhuangzi 25/76/11). These examples demonstrate that "myriad things" is as special and essential as other Daoist concepts such as "dao" ，“potency 德 (de)”, “one一 (yi)” , “transformation 化 (hua)”, “being 有 (you)”, “not/none- 無 $(w u) ”, “ n a m e$ 名 (ming)”, and “self-so/self-affirm 自然 (ziran)”. These concepts jointly form the theoretic cornerstones of the Daoist philosophical framework.

"Myriad things" is a collective name that refers to all of the existing entities in the universe. In other words, the "myriad things" is the "world" . Allan rightly pointed out that "things 物 $(w u)$ " in the ancient Chinese contexts refers not merely to living things but also to non-living entities, including earth and stones indiscriminately (Allan 2014, p. 113). Wang Zhongjiang 王中江also noted that, "Those which have form, image, name, and can be sensed are considered 'things' or the 'ten thousand things' and exist as particularized phenomena" (Wang 2016, p. 60). Yet, if wu refers to all the things there are, what purpose does wanwu serve? The most important difference between wanwu "myriad things" and wu "things" is such that the perspective of "myriad 萬 (wan)" fundamentally connects all things and the innumerable different things that there are, with or without our knowledge of their particularities. This point of view is central to the Daoist way of thought and the way philosophical questions were posed.

Firstly, how do things operate themselves as “selves 自 (zi)” , individuated among innumerable others? As for the way each thing exists, each is as it is in accordance with "spontaneous self-so/self-affirm 自然 (ziran)” . In that case, how do the myriad variegated things achieve spontaneous self-so? Since the variegated multitude of existing things are individually distinct, they ought not to be governed by any specific, fixed, and unified principle, i.e., the Daoist principle of “non-action 無為 (wuwei)”. On what basis do these variegated things grow and develop continuously as they do, when they are not interfered with externally? From the perspective of the spontaneous and autogenous growth and development of all things, that basis is its innate principle and innate ability, i.e., “potency 德 $(d e)$ " ${ }^{6}$ Finally, the natural course through which the myriad things exist, grow,

6 The traditional translation of “de” is “virtue”. However, Graham (Graham 1986, p. 7) translated “de” in the Zhuangzi as "power" . He pointed out that "the spontaneous aptitude is the te, the 'Power' , the inherent capacity of a thing to perform its specific functions successfully. (As an English equivalent of te, many translators prefer 'virtue' , to be understood however as in 'The virtue of cyanide is to poison' , rather than as in 'Virtue is its own reward' )." Michael (Michael 2005, pp. 112-13) noticed the physical level of signification of $d e$; hence, he suggested: "De designates the power of bodily circulation; ideally, this is to remain sealed up within, allowing it to replenish and rejuvenate." He also raises the differences between the de of early Confucianism and early Daoism: "Understanding the physicality invested in this term $(d e)$ makes apparent the difference between the early Daoist usages of de as 'power' or circulation and the early Confucian usages of de as 'moral charisma' or virtue.” Based on Graham' s discussion, Allan (Allan 2014, pp. 115-19) opted for "potency" to translate " $d e$," as she pointed out that " $d e$ " is a hereditary, unique, and natural potential that is yet to be developed, whereas "xing 性 (nature)" is something that every person has. 
develop, and transform is " $d a o$ " . The coming together and the resolution of the myriad things can also be thought of as manifestation of the perennial flow of $q i$ between yin and yang. ${ }^{7}$ The change in the mode of existence of the myriad things is reflected in the emergence and discussion of the concept of “transformation 化 (hua)" . The distinctiveness and significance of “myriad things” shows not only that Daoism was the school most interested in the generation of the universe (Chen 2017, p. 32), but also that it puts forward a philosophy of life concerning how all different things exist as authentic unto themselves and preserving the immanent values of each individuals. Since the academic research on the former (cosmology in Daoism) has been quite fruitful, the focus of this paper will be on the latter (the philosophy of life concerning each individuals in Daoism).

In contrast to the Confucian differentiation between "human 人 (ren)" against animals and non-living objects, which goes hand-in-hand with their neglect of the "myriad things" , the Daoist conceptions of “things 物 $(w u)$ ” and “myriad things萬物 (wanwu)”, ( "humans” included), are apt to broaden one' s philosophical horizon to the extent where the innumerable, co-existing, mutually distinct, and irreducible individuals become immanently evident. Only such a panoramic and all-embracing horizon can possibly afford us insights into a more comprehensive self-realization.

\section{Human Essentials and Being without Human Essentials}

To an extent, the significance of "myriad things" in the Zhuangzi lies in its challenge to the idea of "human 人 (ren)" . More specifically, the proposition of “myriad things” counterargues against principles that hold that "human" represents a unifiable whole with an identical and identifiable essence, regardless of what this essence should be. When "human" is considered as universal, any conscious or subconscious definition of "what humans are" inevitably separates "human" from the myriad things. Purported definitions of this kind often come under the heading of “essence and fact of the humankind” , or “essence of the humankind 人之情 (ren zhi qing)” (Mengzi, ICS Mengzi 11.8/59/16), or “that-which-humans-are-born-with” . More often than not, such definitions reference a common moral essence shared by all human beings, but not animals or inanimate objects. In contrast, the proposition of “being without human essentials 無人之情 (wu ren zhi qing)” (Zhuangzi 5, ICS Zhuangzi 5/15/17), “the essentials of heaven 天之情 (tian zhi qing)” , and “the essentials of the myriad things 萬物之情 (wanwu zhi qing)” in the Zhuangzi is, at its core, is a counterargument against this essentialist trend of thought.

Munro (Munro 1969, p. 130) rightly commented that Daoist thinkers never separate human beings from other animals. Instead, their aim is to put an end to the idea of human uniqueness. He wrote, "The Taoist sage would never distinguish himself from other animals, but would easily consider himself now as a horse, now as an ox, and so forth. The special qualities that human have are temporal, and are thus insignificant. The whole intent is to end the thought about man' s uniqueness, and to drive man from the center of the stage. Munro quoted the words of Hou Wai-lu, "Chuang Tzu sends man from earth to Heaven, and thus denies even the actuality of man.” As Benjamin Schwartz stated, Zhuangzi views that "the distinctly human consciousness is precisely what alienates him from the “dao'” (Schwartz 1985, p. 277). “Essentials 情 (qing)” in the ancient Chinese context implies “fact” (Hansen 2013, p. 273). The “essentials (qing) of X” refers to something that is

7 'Everything in motion in the universe is activated by $c h$ ' $i$, 'breath, energy', conceived as a fluid which in its purest state is the breath which vitalises us ... all energies not only in the body but throughout the cosmos are classed as Yin or Yang, accounting for the alternations of dark and light and of all other opposites” (Graham 1989, p. 7). 
indispensable to X. Angus C. Graham translated qing into "essential” and also regarded that this "essential" of a thing serves as the content of a definition of that thing. Therefore, a thing is in its true existential state only when it realizes the "essentials ( "essence" , "fact" )" of that thing as itself and not as any other thing. In this sense, the essence of an object contains within itself an inherent reality. Only when one grasps the essentials of an object and realizes it can one say that this object is real and authentic. Consequently, a discussion of “human essentials 人之情 (ren zhi qing)” is a deliberation of the authentic existential condition of humans as humans. Fundamentally, "human essentials" represent the essential property that makes humans humans based on the presumption that humankind is to be treated as a unified whole. Humanism emerges when this essentialist position is applied to humans.

One does not lack companions if one believes "humans" to be superior to objects and animals. Example of this popular trend of thought can be found in the Great Declaration 泰誓of the Shang Shu尚書, where it declares, “Of the myriad things human is the most highly endowed. 惟人萬物 之靈” . 8 The definition of "human” as "that which differentiates herself from animals" also demonstrates a similar position. When looking for an essence that grants humans their superiority over animals and objects, thinkers often argue for one that is imbued with moral significance, which, in turn, poses an external and artificial limitation upon "human" beings. In other words, humans rise up above animals by becoming moral beings. For example, Mencius pointed at "the heart-mind of benevolence and righteousness 仁義之心 (ren yi zhi xin)” (Mengzi, ICS Mengzi 11.8/59/12) when discussing "human essentials" and "goodness" . He said in the Gaozi A., "To these things is owing the bare and stripped appearance of the mountain, and when people now see it, they think it was never finely wooded. But is this the nature 性 (xing) of the mountain? And so also of what properly belongs to a person; shall it be said that the mind of any person was without benevolence and righteousness? ... When this proves insufficient for that purpose, the nature becomes not much different from that of the irrational animals, and when people now see it, they think that it never had those faculties 才 (cai) which I assert. But does this condition represent the human essentials 情 (qing)?" (Mengzi, ICS Mengzi 11.8/59/11-17) and "Whatever that is appropriate to her essentials, it is constituted for the practice of what is good.” (Mengzi, ICS Mengzi 11.8/58/20) In these two passages, “essentials 情 (qing)”，“faculty 才 (cai)”, and “nature 性 (xing)” are clearly related. They refer to the "inherent and authentic essentials and fact" as well as the abilities and nature of a thing or a person. For Mencius, goodness is attained only when one follows her essentials. This represents a moralization built upon an essentialization of what it means to be human.

Zhuangzi, on the other hand, offers a different take on what "human essentials" amounts to. This topic is discussed twice in Zhuangzi 5:

She has the shape of a person, but is without human essentials (qing). She has the shape of a person, and therefore congregates with humans; she is without human essentials (qing), and therefore "That' s it, that' s not" are not found in her person. Indiscernibly small, that which attaches her to human. Unutterably vast, the heaven within her which she perfects in solitude. (ICS Zhuangzi 5/15/17-18)

8 See Shang Shu Zheng Yi 《尚書正義》 (十三經註疏本), edit. Shangshu zhengyi zhengli weiyuanhui 尚書正義整理委員會, Beijing: Beijing daxue chubanshe, 2000. p. 321. The Great Declaration 泰誓 of the Shang Shu 《尚書》 is commonly seen as fraudulent additions made by pseudo-archaic authors. Nonetheless, the argument for the superiority of humans over the myriad things is prevalent in pre-Qin Confucian texts. 
Huizi says to Zhuangzi, "Can a person really be without human essentials?" Zhuangzi then replies, "She can." Huizi says, "If a person is without human essentials, how can we call her a person?" Zhuangzi says, "Dao gives her the guise, heaven gives her the shape, how can we refuse to call her a person?" Huizi asks again, "But since we do call her a person, how can she be without human essentials?" Zhuangzi answers, "Judging 'that' $s$ it' and 'that' s not' is what I mean by 'human essentials'. What I mean by being without human essentials is that the person does not inwardly wound her person by likes and dislikes, that she constantly goes by the spontaneous self-so and does not add anything to her nature." 9 (ICS Zhuangzi 5/15/20-23)

The initial statement that Hui Shi asked in the second paragraph is not about the ordinary state of humans (referring to the artificial aspects of a human being), but about the original or authentic state (Michael 2005, pp. 122-23). We also find a similar phrase in Zhuangzi 1, where the "spirit-like person 神人 (shen ren)" is said to be “nowhere near human essentials as she really is 不近人情 (bu jin ren qing)" (Zhuangzi 1, ICS Zhuangzi 1/2/14). As such, the "spirit-like person” is nigh to "an 'authentic and real essential and fact'” . (Chen 2014) Clearly, the "essential” that Zhuangzi rates higher than all others is not "human essentials" , but rather “essentials of the heaven 天情 (tian qing)", which could be understood as "the original or authentic state" .

If human morality represented by "benevolence and righteousness" is what differentiates humans from animals, then the standard of "benevolence and righteousness" leads naturally to “judging 'that' sit' and 'that' s not'”, which in turn results in likes and dislikes 好惡 (hao wu). Conversely, "being without human essentials" exempts one from being attached to "that' $\mathrm{s}$ it" and "that' s not", not to be troubled by likes and dislikes, and could "go by the spontaneous self-so and add not anything to her nature." Chu Boxiu notes, "With one' s own nature and essentials, one repairs oneself to the spontaneous self-so” (Fang 2012, p. 727) “To be without essentials 無情 (wu qing)" is to eliminate "human nature and essentials" and repair oneself to "one' s own nature and essentials" , namely, "one' s spontaneous self-so" by ensuring the realization of "what is responsible for the fact being is that which it is" (Chan 2005, p. 540). Zhuangzi' s advocation of "being without human essentials" asks one not to "become human" , but rather to follow "the essentials of the heaven" by "perfecting in solitude the heaven that is within each individual" (Wang 2013, p. 94). Cui Zhuan noted that, "being the same in kind with human amounts to that which is small, being congruous in essentials to the heaven amounts to that which is large" (Fang 2012, p. 727). In this light, it is clear that "the essentials of the heaven" is the "spontaneous self-so" , which is in turn identified with "the essentials of myriad things" . The proposition of "being without human essentials" is made regarding the broader intellectual topic of the relationship between heaven and human (Chen 2014).

Nonetheless, Zhuangzi' s critique of “human essentials” does not entail an opposition to the idea of "humankind" . The Zhuangzi acknowledges that things are separated into different kinds. However, it also argues that "the myriad things produce one another by forms 萬物以 形相生” (Zhuangzi 22, ICS Zhuangzi 22/61/11). Zhuangzi 6 states that each object “undergoes

9 For the English translation, see Wandering on the Way: Early Taoist Tales and Parables of Chuang Tzu, trans. Mair (1994); The Complete Works of Chuang Tzu, trans. Watson (1968); Chuang-tzu: The Seven Inner Chapters, trans. A. C. Graham (London: George Allen \& Unwin Ltd., 1981); also Zhuangzi: the essential writings with selections from traditional commentaries, trans. Ziporyn (2009). I have made some changes and paraphrases throughout passages. 
a myriad transformations and not once reaches perfection 万化而未始有极”，and humans are by no means superior to any other object, as they participate unvaryingly in this great stream of constant transformations. Things, as we see them, are different with respect to their shape, color, faculty, and nature, but not their moral value. According to Zhuangzi 19, one thing is different from another for “no more but their outward appearance 是色而已” (Zhuangzi 19, ICS Zhuangzi 19/50/1). Consequently, to universalize “the essentials of myriad things 萬物之情” in abstraction is fundamentally impossible and unattainable. Zhuangzi 25 says, "the principle 理 (li) of myriad things are different 萬物殊理 (wan wu shu li)”. Zhuangzi 17 also reminds us of the differentia of things; it emphasizes “the uses of things are different 殊器 (shu qi)” , “the gifts of creatures are different 殊 技 (shu ji)”, and “the natures of creatures are different 殊性 (shu xing)” . (ICS Zhuangzi 17/44/30-32) Zhuangzi 2 argues that what is "right 正 (zheng)" for each individual is particular to its kind, and not to be conceived of in abstraction:

Gaptooth puts a question to Wang Ni.

“Would you know something of which all things agreed, 'That' s it' ?”

"How could I know that?"

"Would you know what you did not know?"

"How could I know that?"

"Then, is there no knowing of things?"

"How could I know that? Not with standing, let me try to say this: How do I know that what I call knowing is not knowing? How do I know that what I call not knowing is knowing?"

"Moreover, let me try a question on you. When a person sleeps in the damp, her waist hurts and she gets stiff in the joints; is that so of the loach? When she sits in a tree she shivers and shakes; is that so of the ape? Which of these three knows the right place to live? Humans eat the flesh of hay-fed and grain-fed beasts, deer eat the grass, centipedes relish snakes, owls and crows crave mice; which of the four has a proper sense of taste? Gibbons are sought by baboons as mates, elaphures like the company of deer, loaches play with fish. Mao Qiang and Lady Li were beautiful in the eyes of men; but when the fish saw them they plunged deep, when the birds saw them they flew high, when the deer saw them they broke into a run. Which of these four knows what is truly beautiful in the world? In my judgment, the beginnings of good will and right conduct, the paths of "that' $s$ it, that' $s$ not” , are inextricably confused; how could I know how to discriminate between them?” (ICS Zhuangzi 2/6/9-15)

As Zhuangzi articulately demonstrates, things of different kinds are born with different natures, which give them different standards. What is right for humans does not represent what is right for "all under heaven" . The Zhuangzi admits that things of the same kind share certain common features and characteristics; for example, "humans eat animals that have been fed on grain and grass" , or that Mao Qiang and Li Ji are seen as beautiful women. However, Zhuangzi' s affirmation of common features and characteristics for "humankind" does not lead him to believe that there is an identical moral essence that is universal to all human beings. There are two arguments for Zhuangzi' s position. Firstly, one must ask whether one could identify the things that she does not know; secondly, one can only look inward and learn about oneself. Just as one cannot escape the reflexive limitation of the 
epistemological problem "how to know what one does not know" , how could one learn of "that which all things are 'the same' (同是 'tong shi' )” ? Similarly, how could one learn the "right appearance, right place, right position" ? Therefore, the Zhuangzi withholds knowledge on the abstract standard of "right" and its resultant "benevolence and righteousness, 'that' s it' and 'that' $\mathrm{s}$ not' 仁義是非 (ren yi shi fei)” , and claims that it is questionable that whether one can truly know matters of this kind. Thus, "the first principles of benevolence and righteousness and the paths of 'that' s it' and 'that' s not' are inextricably mixed and confused together-how is it possible that I should know how to discriminate between them? 仁義之端, 是非之塗, 㚞然殽亂, 吾惡能知其辯” .

If moral principles are not universally identifiable and accessible, it loses its candidacy for "human essentials" as the basis for the differentiation of humans above animals. Furthermore, the Zhuangzi argues that “benevolence and righteousness, 'that' $\mathrm{s}$ it' and 'that' $\mathrm{s}$ not' 仁義是非” are "human punishments” that are capable of doing great injury to one' s heart-mind and nature. It strips one from the ability to freely flow and transform in the great road of transformations. Zhuangzi 6 states that, "Yao has already tattooed your face with benevolence and righteousness and de-nosed you with right and wrong. How will you be able to wander in the way of aimless enjoyment, of unregulated contemplation, and the ever-changing forms?" (ICS Zhuangzi 6/19/9-10). If one were to substitute the manifold living conditions with the singular morality of benevolence and righteousness, or for that matter, any moral essentialist theory, one would inevitably fracture and divide the authentic existence of concrete individuals. The Zhuangzi calls this “altering one' s inborn nature with benevolence and righteousness 以仁義易其性” and “a great confusion altering one' s inborn nature 大惑易性” (ICS Zhuangzi 8/22/28). Therefore, the Zhuangzi says, “Forgetting the Human makes you a human of the Heavenly 忘人因以為天人” (ICS Zhuangzi 23/67/21-22).

\section{The Authenticity of Nature and Essentials- "Myriad Things", "Self-so (Ziran)", and "Non-Action (wuwei)" between "Heaven and Human"}

According to the Zhuangzi, an “Authentic Human Being 真人 (zhen ren)” is inseparable from her own nature and essentials. Just as "being without human essentials" is related to "essentials of heaven" , Zhuangzi' s treatment of the authentic human being is also given in the framework of "heaven-human." In the inner chapters, the "Authentic Human Being" is discussed only in Zhuangzi 6; two of the instances are given directly in relation to the "heaven-human" theoretical framework, and both blur the rigid division between the two realms. The concept of the authentic human being breaks away from that of "heaven" versus the "human" structure:

"However, there is a problem here. For our understanding can be in the right only by virtue of a relation of dependence on something, and what it depends on is always peculiarly unfixed. So how could I know whether what I call the Heavenly is not really the Human? How could I know whether what I call the Human is not really the Heavenly? Let us say instead, then, that there can be "Authentic Knowledge" only when there is such a thing as an “Authentic Human Being.” And what do we mean by an “Authentic Human Being” ? ... not to use the mind to resist the Dao, not to take attempts by means of the Human to assist the Heavenly. Such is what I' d call being an Authentic Human Being” . (ICS Zhuangzi $6 / 15 / 29-32)$

"Heaven and the human do not overcome one another; such were those who are called the authentic persons” . (ICS Zhuangzi 6/16/19-20) 
In the outer and miscellaneous chapters, a person being authentic is one who is "a person in appearance but has an empty (heart-mind) of heaven” 其為人也真，人貌而天虛” (ICS Zhuangzi 21/56/18). The authentic persons of ancient times "treated the Heaven heavenly, and did not intrude into the Heavenly with the Human” 古之真人, 以天待之, 不以人入天 (ICS Zhuangzi 24/72/12). Also, Zhuangzi' s position on the "heaven-human" problematique is indicated by the concept of "purity 純 (chun)”, “simplicity 素 (su)”, and “whiteness 白 (bai)”. Zhuangzi 15 says, “It is she who can embody simplicity and purity whom we call the authentic person” 能體純素, 谓之真人 (ICS Zhuangzi 15/42/14). The authentic person is someone who follows “the path of pure simplicity純素之道 (chun su zhi dao)" , which "becomes one with the spirit; and in this ethereal amalgamation, acts in harmony with the orderly operation of Heaven” 與神為一, 一之精通, 合於天倫 (ICS Zhuangzi 15/42/12). Since the authentic person represents she who can embody these ideals, as it is described in Zhuangzi 12 , "she lightens up her insight so as to [let] the simplicity emerge, and by inactivating deliberate actions, she returns to the original state, embodying her nature and holding her spirit” 明白入素, 無為 復樸, 體性抱神 (ICS Zhuangzi 12/32/22). “Purity 純 (chun)”, “whiteness 白 (bai)”, and “simplicity 素 (su)” all represent the original state, as it were, free from interference by others. The authenticity of this state of attainment is warranted by the heaven, i.e., ordinance by "the essentials of the heaven" or “the spontaneous self-so 自然 (ziran)”. Thus, we see a cluster of concepts involving "heaven” ，“self-so 自然 (ziran)”，“authenticity 真 (zhen)”，“nature 性 (xing)”, as well as “ordinance 命 (ming)” . Zhuangzi 31 confirms this interrelation by saying that "authenticity is that which is received from Heaven, operating spontaneously, and should not be replaced. Hence, the sages model themselves on Heaven and value [the] authenticities of myriad things” 真者, 所以受於天也，自然不可 易也, 故聖人法天貴真” (ICS Zhuangzi 31/94/10-11).

When Zhuangzi 23 mentions, “recover your proper essentials and nature 反汝情性 (fan ru qing xing)" (ICS Zhuangzi 23/65/6), it is the same as calling to “returning to one' s own authenticity 反其 真 (fan qi zhen)" (ICS Zhuangzi 17/45/18). Zhuangzi 17 also admonishes, "Do not use the Human to extinguish the Heavenly; do not for your purpose extinguish the ordinance of Heaven; do not sacrifice what you have attained for the sake of mere names; carefully guard this way and do not lose it: this is what I call returning to your own authenticity" (ICS Zhuangzi 17/45/18). "Nature 性 (xing)" is a key concept with which things realize their own authenticity. ${ }^{10}$ The realization of what is different from other things and becoming itself or herself rather than the other is the authentic manifestation of that thing or person' s existence. That is to say, the display and practice of the "essential properties" of a thing or a person is a prerequisite for its/her authentic existence as itself/herself. Examples in the Zhuangzi including the "authentic nature 真性 (zhen xing)" of the horse (ICS Zhuangzi 9/23/18) and "for the sake of gain they all disallowed their authenticity, and did violence to its proper essentials and nature" (ICS Zhuangzi 29/88/6); these passages show that authenticity, essentials, and nature are intricately connected concepts.

Zhuangzi's “heaven 天 (tian)" in this concept cluster is neither the Heavenly-god as a religious transcendental being, nor the humanistic rationalized heaven of "The heaven sees according to what

10 It must be noted that the word “nature 性 (xing)" is not found in the inner chapters of the Zhuangzi. Wang Yu-bin (Wang 2017) believed that Zhuangzi chose this omission carefully, opting to use the word “potency (de)" instead. Advantages of this preference include, firstly, " $d e$ " is beyond good and evil and bears only upon authenticity and inauthenticity; secondly, "de" warrants the affirmation of individual differences, against "universal nature" , which treats the myriad things in abstraction; thirdly, " $d e$ ” represents a multi-polar worldview that treats every existing and transforming thing with respect, rather than as an object of dominance and cultural indoctrination. 
people see; heaven hears according to what people hear 天視自我民視，天聽自我民聽” (ICS Mengzi 9.5/49/1). "Heaven" signifies all that exists, namely the "myriad things" (emphasis on the side of substantive entity) and also “ziran 自然” (emphasis on the side of ontological state of being). In Guo Xiang' s annotations to Zhuangzi 2, he wrote, "Heaven is the collective name of the myriad things” ; Cheng Xuan-ying added that "Heaven is the collective name of the myriad things as well as another name for ziran" . Similarly, Roger Ames and David Hall commented that the myriad things are not creations of heaven that are transcendent above the laws governing the cosmos, but rather, the myriad things are what constitute heaven (Ames and Hall 2003, p. 65). Hans-George Moller also believed that heaven and the myriad things under heaven are inseparable (Moeller 2010, pp. 57-58). This could explain why in Daoist texts, "myriad things", "heaven and earth" , and "all under heaven" are often mutually defining concepts.

The mutually penetrating relation between "heaven" and "myriad things" is the foundation upon which “ziran 自然” and “tianra 天然” in modern Chinese could encompass meanings such as “nature” and "natural” . As Wang Zhongjiang remarked, "The Daoist concept of 'naturalness' ziran 自然 as a non-substantive state for the individual conditions of all the myriad beings” (Wang 2016, p. 133). The Daoist "heaven" as a "collective name for the myriad things" is not a totality, but rather a collective of irreducible individuals. It does not mean a transcendent moral authority, but instead bestows equal authority and significance on each individual being. The "principles of the myriad things 萬物之理 (wan wu zhi li)" are rightly said to be "variegated principles of the myriad things 萬物殊理 (wan wu shu li)" in Zhuangzi 25. In contrast to the "humanization" of heaven championed by Confucian thinkers, the Zhuangzi identified "heaven" with "ziran". In terms of state of being, "ziran" means the being "self-so" of all existing things; whereas in terms of evaluative judgment, "ziran" can also means the "self-authorization" of all existing things. Considering that the monistic value of "human essentials" does not take precedence over the "ziran" of "myriad things," the moral message conveyed by “the myriad things being spontaneously self-so 萬物自 然 (wan wu ziran)” is such that one realizes her “potency (de)” not by conforming to what makes a person a person, but by realizing what makes each individual in the myriad things an individual of her own.

In a sense, the authentic person is the “person of utmost potency至德者 (zhi de zhe)” (ICS Zhuangzi 17/45/14). Zhuangzi 6 describes that the authentic person of ancient times "submerges into the depths without getting drenched, enters the fames without being burnt" . Zhuangzi 17 also says that "the person of utmost potency is not burnt by fire, or drowned by water" . Concerning authenticity and potency, Zhuangzi 19 advises, "Do not develop the Heaven of Human, but the Heaven of Heaven. Developing the Heaven grows the potency; developing the Human grows hurt. Fulfill the Heaven, but do not neglect the Human either. Then, people would almost come to live by what is authentic in them" (ICS Zhuangzi 19/50/9-10). At the end of the inner chapters, Zhuangzi 7 starts with a discussion of the king Tai, whose "potency is utmost authentic" . King Tai also renounces “benevolence 仁 (ren)” for the “(authentic) human 人 (ren)” , and “would consider himself now (merely) as a horse, and now (merely) as an ox, 一以已為馬, 一以已為牛” and he “had not begun to proceed by what belonged to him as a human 未始入於非人” (ICS Zhuangzi 7/10/4-6).

Zhuangzi 21 also depicts a paradoxical person embodying both the "non-human 非人 (fei ren)” and the "utmost human 至人 (zhi ren)" : Confucius meets the freshly bathed Lao Dan, who appears “motionless and almost resembling a non-human. 熱然似非人” (ICS Zhuangzi 21/57/20). Lao Dan responds to the astounded Confucius, saying, "I am wandering myself in the commencement of 
things 吾游心於物之初” (ICS Zhuangzi 21/57/22). As Confucius asks again of his enjoyment in these thoughts, Lao Dan replies that obtaining this “is called the utmost human 謂之至人” (ICS Zhuangzi 21/58/2). Is it not strange that the "utmost human" who has her mind wandering in the commencement of things, has the appearance of a "non-human" ? This story implies a viewpoint that treats humans primarily as a part of the myriad things before they are seen as a collective consisting of the members belonging to humankind. In this regard, the "utmost human" contains within herself an individual particularity that is irreducible and irrelevant to the essentialist understanding that takes for granted the totality of humankind as a unified whole. In other words, the Zhuangzi views human beings as variegated individuals instead of a totality. Accordingly, there seems to be no better source of existence for life than realizing oneself by making one' s potency authentic, whereby each individual lives in accordance with her own spontaneous self-so essentials and nature, and thus is self-authorized.

Bringing this to the political level, the Zhuangzi advocates that the meaning and necessity of a ruler' s existence is to help “settling安 (an) each of the myriad things can live in concordance with her essentials of nature and ordinance命 (ming) 安其性命之情” (ICS Zhuangzi 11/26/25). Settling安 (an) is neither excessive nor inadequate. Zhuangzi 11 explains that "the existing of the rulers is from the fear that the myriad things will carry their nature beyond their own normal condition; and the warrant of the rulers is from the fear that the myriad things will distract their potency 在之也者, 恐天下之淫其 性也; 宥之也者, 恐天下之遷其德也” (ICS Zhuangzi 11/26/9-10). “Nature” and “potency” are not universals such as "human nature" or "moral nature", which are thought to be applicable to all human beings. Instead, each of the myriad things has her own nature, particularities, and potencies. Therefore, "settling安 (an)” each of the myriad things in concordance with her essential nature and potency must mean “non-action 無為 (wuwei)” in political terms. Zhuangzi 7 criticizes that in cases where "the ruler is one who issues canons, patterns, rules, and regulations on his own authority. Who would dare not obey them and be transformed by them? 以己出經式義度, 人孰敢不聽而化諸” ; such behavior would lead only to “deceptive potency 欺德 (qi de)” instead of “authentic potency 真德 (zhen de)” (ICS Zhuangzi 7/20/8-9).

In the Zhuangzi, the ideal political order is holding the "straightness 正 (zheng)" . "Straightness 正 (zheng)” and “potency 德 (de)” are connected; “potency (de)” is related to “straight 直 (zhi)” in the oracle-bones script. The earlier alternative form of potency (de) is written as 息, and is constituted of “straight 直 (zhi)” and “heart-mind 心 (xin)”. As Shouwen Jiezi 說文解字explained, Zhi 直is “looking straight 正見 (zheng jian)” (Li 2004, p. 1002). Its derived sense is looking straight into the heart-mind. Roger Ames suggested that the meaning of straight is "perhaps better understood in its more fundamental meaning of 'to grow straight without deviation' in the context of organic issuance” (Ames 1989, p. 125). Zhuangzi 6 says that, “Although all life forms receive their nature from heaven, it is only the King Shun who is straight. Just as well, he can straighten his own nature so as to straighten out others as well.” The ideal ruler, for Zhuangzi, is one who is capable of straightening the nature of the myriad things, helping them retain and guard their own individual original nature. Zhuangzi 8 says that, "The one who straightens the straightness is just not to lose the essentials of one’ s inborn essentials of nature and ordinance 彼正正者，不失其性命之情” (ICS Zhuangzi 8/22/13). Similarly, Zhuangzi 16 argues that, "When things are straight and full, they are upheld by the ruler' $\mathrm{s}$ potency. The authentic potency is not to offend the potency of myriad things. If an attempt be made to force it to extend, then things would invariably lose their inborn nature 彼正而蒙己德，德則不冒，冒則 物必失其性也” (ICS Zhuangzi 16/42/21-22). As such, political rulers ought to govern with a clear understanding of “straightness 正 (zheng)" whereby there is no such thing as a universal standard 
"straightness" for myriad things under the Heaven. According to Guo Xiang, the "mounting on what is straight of heaven and earth" described by Zhuangzi 1 is allowing the myriad things to “self-straighten 自正 (zi zheng)” (Guo 1997, p. 20). On “self-straightening” , Zhuangzi 8 says that,

"If we must use [a] curve, plumb line, compass, or square to make something straight, this means cutting away its inborn nature; if we must use cords and knots, glue and lacquer to make something firm, this means violating its natural potency.” (ICS Zhuangzi 8/22/21-22)

Therefore, the ideal ruler practicing “non-action 無為 (wuwei)” should, on the one hand, refrain from using his power to formulate any standard, but instead work to make sure that each of the myriad things retains the power to formulate her own standards, and on the other hand, work to guarantee and assist in the "straightening 正 (zheng)" of each of the myriad things in accordance with her straight nature and potency, thus allowing all to become their "authentic" selves— "non-action 無 為 (wuwei)” leading to “spontaneous self-so 自然 (ziran)”.

The meaning of "ziran" must be understood with reference to the "myriad things". The myriad things contain all existing entities. The "ziran" of each entity in the myriad things are different, albeit they are all "ziran”. Dao 道, for which the existence of all things is warranted, permeates in the myriad things. Dao is the all-pervasive “that which makes things things物物者” , which “finds itself boundary-less with all things 與物無際 (yu wu wu ji)” (ICS Zhuangzi 22/62/8-9). “If we look at the myriad things from the perspectives of $d a o$, (we see that) their response is well prepared 以道汎觀而萬 物之應備” (ICS Zhuangzi 12/29/14). “Dao does not end itself in what is greatest, nor does it ever lose itself from what is least; and therefore, the myriad things are all well prepared 夫道, 於大不終, 於小不遺, 故萬物備” (ICS Zhuangzi 13/36/31). “Potency (de)” is the intrinsic power and property by which the myriad things sustain themselves. Zhuangzi 12 says that "de is that by which things grow 物得以生謂之德” (ICS Zhuangzi 12/31/10). Each of the myriad things has its own nature of potency according to which it could develop. On this, Yu Yue noted, "De is by which there is growth" (Zhong 1988, p. 545). As such, Daoist key concepts including “dao” , "potency (de)” , and “ziran” are all ultimately rooted in the concept of "myriad things" .

The Zhuangzi contends that the essentials of the nature and ordinance of the myriad things, namely the authentic condition of the myriad things as they are, is such that, "The duck' s neck may be short, but lengthening it would surely vex him; the swan' s neck may be long, but cutting it short would surely sorrow her 鳥脛雖短續之則憂, 鶴脛雖長㫁之則悲” (ICS Zhuangzi 8/22/14). Therefore, it argues, "bending and scraping by following the setting ritual and music, warmly eulogizing benevolence and righteousness to comfort the hearts of everyone in this world屈折禮樂, 昫俞仁義, 以慰天下之心者” is “missing the constant state of myriad things in their selves 失其常然” (ICS Zhuangzi 8/22/22). Furthermore, the Zhuangzi recognizes that "all things have their own constant state 常然 (chang ran)”. “The constant state of things常然 (chang ran)” is such that “What is curved is not made so by the hook, nor what is straight by the line, nor what is circular by the compass, nor what is rectangular by the carpenter's square 常然者，曲者不以鉤，直者不以繩，圓者不以規，方者 不以矩” (ICS Zhuangzi 8/22/23). In fact, “The constant state of things (chang ran)” is equitable to “self-so/self-affirm (ziran)” (Wang 2018, p. 50). ${ }^{11}$ Things are, respectively, long and short, curved

11 As Wang Bo 王博 analyzed, the concept of ziran 自然 contains two aspect of meanings: the existential sense and the norms of value. In the sense of existence, ziran 自然 is understood as "self-so”, which approves the ontological state in things as 
and straight, square and rounded by themselves. As such, there is no need to establish what the measure of "straightness (zheng)" is as a universal standard by which the long is shortened and the short lengthened. The myriad things all make right by themselves in accordance with what is "straight" for them, and they all act in accordance with what is appropriate, and do not deviate from their nature. “The constant state of all things under heaven 天下有常然” (ICS Zhuangzi 8/22/22) is the spontaneous self-so of the myriad things. The same state of affairs is said to be "ziran" from the perspective of state of being; it is said to be the "essentials" , "nature” , "ordinance”, and “essentials of nature and ordinance 性命之情 (xing ming zhi qing)" from the perspective of existential meaning.

What needs to be further clarified is that the Daoist understanding of "self-so/self-affirm(ziran)" never implies a definition of “essentials and nature 情性 (qing xing)" with reference to “desire 欲 $(y u)$ ” . Desires externally provoked are repeatedly treated with caution in the Zhuangzi. Zhuangzi 5 writes that "the darker one' s lusts and desires are, the lighter their 'motors 機 (ji)' of the heaven are" (ICS Zhuangzi 6/16/3); Zhuangzi 24 warns that "if [you] go on to fill up your lusts and desires, and prolong your likes and dislikes, then the essentials of your nature and ordinance will become ill 盈耆欲, 長好惡, 則性命之情病矣” (ICS Zhuangzi 24/67/29). These admonitions against giving in to one' s own lust and desires are accompanied by theories on dissolving oneself, fasting of the mind 心 齋 (xin zhai), and sit-forgetting 坐忘 (zuo wang). Therefore, following one' s spontaneous self does not mean that one should pursue every fleeting desire. This informed understanding of Zhuangzi' s position on desire then pre-empts John Stuart Mill' s criticism of “nature is good” , according to which nature is an object to be subdued and led, and that all executed criminals and prisoners in prison are the best representatives of conforming to nature. ${ }^{12}$

The Zhuangzi values individuals for being authentic themselves, but with a distinctive paradoxical tension between “being self 成己 (chenji)” and “losing self 坒我 (sangwo)”. In this position, it is different from modern individualism or liberalism. Being an authentic self, or an authentic person demands exemplifying the authenticity of the utmost potency and fulfilling one' s own inner nature, which also necessitates oneself to empty one' s heart-mind and purify one' s spirit in order to eliminate external interference. Hence, this self-reflection and self-cultivation approach avoids the malaise that being as oneself will lead to one becoming Nietzsche' s "last men" who has no aspiration left in life but to a "pitiable comfort" . In The Ethics of Authenticity, contemporary philosopher Charles Taylor wrote,

Herder put forward the idea that each of us has an original way of being human. Each person has his or her own 'measure' is his way of putting it. This idea has entered very deep into

themselves and requires that things should exist to be so, whereby leads to the original Daoist theory of “non-action 無為 (wu-wei)" and the negation of the Creator; In the sense of value, ziran 自然 is understood as "self-affirm” , which tends to legitimate the self-justification that the normativity of things are endowed within themselves, thus leads to a political philosophy centered on the “de-norms 無名 (wu-ming)” (Wang 2018). Similarly, Brook Ziporyn addressed that ziran 自 然 has meanings of self-so and self-rightness, "what is self-so, according to Guo (GuoXiang)' s new interpretation of the meaning of this term, is necessarily 'right' 然 $(r a n)$ by definition” (Ziporyn 2003, p. 28) and "what things have in common is their being self-so, their self-rightness. Each thing is inherently right to itself, and this is its identity, the identity that all things share” (Ziporyn 2003, p. 115).

12 “... 'Nearly all the things which men are hanged or imprisoned for doing to one another are nature' s every day performances.' Mill finds nature 'imperfect' and 'murderous' : nature must be subdued and commanded. He insists that we improve on nature at large and man' s nature in particular” (Hyun and Yang 2007, p. 57). 
modern consciousness. It is also new. Before the late $18^{\text {th }}$ century, no one thought that the differences between human beings had this kind of moral significance. (Taylor 1991, p. 28)

About 2300 years ago, the Zhuangzi had already echoed Taylor' s discussion of authenticity,

Not only should I not fit my life to the demands of external conformity; I can' $t$ even find the model to live by outside myself. I can find it only within. Being true to myself means being true to my own originality, and that is something only I can articulate and discover. In articulating it, I am also defining myself. I am realizing a potentiality that is properly my own. This is the background understanding to the modern ideal of authenticity, and to the goals of self-fulfillment or self-realization in which it is usually couched. This is the background that gives moral force to the culture of authenticity, including its most degraded, absurd, or trivialized forms. It is what gives sense to the idea of "doing your own thing" or “finding your own fulfillment” . (Taylor 1991, p. 29)

As for the Zhuangzi, "authenticity真(zhen)" is proposed as an ultimate state of attainment that is identified with the self-realization of each individual being as herself, over and above the so-called moral goodness and its opposite. The Zhuangzi' s concern is the authenticity of the myriad things, and for the myriad things, to be their true selves involves a complex situation that the essentials and identity of myriad things are fundamentally in the state of drifting, along with the flux in a continuous transformation.

\section{Between "One" and "Transformation" : the Continuity and Transitivity of the Essentials of Myriad Things}

If we consider Zhuangzi' s claims on “one - (yi)" and “transformation 化 (hua)" in conjunction, such as “the myriad things and I are one 萬物與我為一” (ICS Zhuangzi 2/5/21-22), “the myriad things are all one 萬物皆一” (ICS Zhuangzi 5/3/14), “the transformations of myriad things 萬物之化” (ICS Zhuangzi 4/10/8), then it is evident that the "essentials of the myriad things" with regard to each individual are nested within a de-essentialized narrative. We are hence led to ask: what is a “thing 物 (wu)" (human included)? What differentiates and separates one "thing” from another? Are "things” different in essence? In Zhuangzi 19, it says,

Whatever has forms, images, sound, and color, is a thing. How, then, is one thing distanced from another? And are there sufficient grounds for giving some precedence over others? They are merely forms and colors, no more (ICS Zhuangzi 19/50/1)

Anything with perceptible qualities, including form, sound, and color etc., is capable of being experienced as a phenomenon, and thus can be identified as a “thing 物 (wu)" . The Zhuangzi argues that since things are differentiated with respect to shape, appearance, sound, and color, and since all things are located in the same realm of phenomenon 色 (se), none within the myriad things can be thought of as superior to any other; none precedes any other. All are situated within the process of transformation. The text then continues to say (ICS Zhuangzi 19/50/2-3), 
I

things are reaching to the formlessness, 則物之造乎不形

The perfect human will dwell within the bounds of the nature with no excess, 彼將處乎不淫之度 unify their nature, nurture their vital breath, cherish

III their potency, 壹其性, 養其氣, 合其德, and ceasing from not being transformed. 而止乎無所化

hide within the borders of

transformation with no inchoation, 而藏乎無端之紀

\section{C}

For once this is attained and thoroughly extended to the end, then whence can things attain their ceasing? 夫得是而窮之者, 物焉得而止焉

wander where the myriad things have their end and beginning, 遊乎萬物之所終始

so as to communicate where all things are going to reach. 以通乎物之所造。

In these three consecutive passages from Zhuangzi 19 where "things” , “the perfect human” , and "the perfect human' s attitude toward nature" are discussed in succession, a close reading of their structure reveals an interlocking parallel style. “Reaching 造 (zao)” (IA), “ceasing 止 (zhi)” (IB), are contrast with “then whence can things attain their ceasing 焉得而止 (yan de er zhi)” (IC) from passage I; this structure is similar in section II, for “dwell 處 (chu)” (IIA) and “hide 藏 (cang)” (IIB) contrast with “wander 遊 (you)" (IIC) in passage II. Finally, "whence all things are going to reach 物之所造 (wu zhi suo zao)” in IIIC resonates with “things reaching to the formlessness 物之造 乎不形 (wu zhi zao hu buxing)” from IA, connecting the beginning and end.

“Reaching 造 (zao)" and “ceasing 止 (zhi)” both signify a state of stop, but they are both succeeded by a transformation that provides no answer to the question, "whence can things attain their ceasing?" Color and form are merely the external appearance of a thing, whose essential fact is that of transformation without cessation. "Formlessness" is not the lack of form, rather a continuous transformation that traverses all forms. To "wander where the myriad things have their end and beginning" is to have an understanding that "beginning and ending go on in mutual contrariety without any determinable commencement, and no one knows how either comes to an end 始終相 反乎無端, 而莫知其所窮” (ICS Zhuangzi 21/57/25). Therefore, the “utmost human 至人 (zhi ren)” expresses Zhuangzi' s ideal state of attainment where one dwells among the myriad things and maintains one' s nature together with the spontaneous self-so of the myriad things, hides with no outward fame or fixed or permanent trait, and always wanders in the transformative continuity of all things.

Zhuangzi 6 describes the state of all existing "things" as follows:

If you could hide the world in the world, so that there was nowhere to which it could be removed, this would be the ever-lasting grand essential of things. The human form is merely a circumstance that has been met with, just something stumbled into, but those who have become human take delight in it nonetheless. Now the human form in its time undergoes myriad transformations, never stopping for an instant, so the joys it brings must be beyond calculation! Hence, the sage uses it to roam in that from which nothing ever escapes, where all things are preserved. She considers early death or old age, beginning and ending, all to be good. In this, other people imitate her; how much more will they do so in regard to That Itself, which ties all things together, on which depends even their slightest transformation, and from which every transformation arises! (ICS Zhuangzi 6/16/27-29) 
What is important in Zhuangzi" s observation here is the "grand essential of things 物之大 情 (wu zhi da qing)”, which is predicated by “ever-lasting 恆 (heng)” . Zhuangzi takes under consideration the grand essential reality of all objects as they come in and out of existence in time ever-lasting. This grand essential is such that everything is constantly being removed from itself per se. An individual may consider that she has comfortably hid away from all others, thinking that she has found a suitable place that could evade change; nevertheless, she is ultimately and inevitably transformed without her knowledge or consent. Similarly, Zhuangzi 17 writes, "the life of things is like the hurrying and galloping of a horse. With every movement there is a change; with every moment there is an alteration. Should you act? Should you refrain from action? Your self-transformation will be affected inevitably nonetheless" (ICS Zhuangzi 17/45/10-11). Immobility is incapable of preserving one against change, which can take place unperceivably. This grand and ever-lasting transformation is described in multiple passages: "The mutual ordering through which they conspicuously revolve, their reversal after reaching an extreme, their beginning after coming to an end. These are the qualities inherent in things 隨序之相理，橋運之相使; 窮則反，終則始; 此物之所有” (ICS Zhuangzi 25/76/19); “The myriad things are all from 'seeds' , and they succeed each other by their different forms. From start to finish, it is like a circle whose seam is not to be found. This is called the celestial potter' s wheel, and the celestial potter' s wheel is the framework of nature" (ICS Zhuangzi 27/79/27; $27 / 80 / 1)$.

To emphasize this vantage point, from which transformation is more primary than form with respect to any existing entity, Zhuangzi 6 goes on to describe how a seriously ill person could possibly have "a chicken for his left arm” , "a cross-bow for his right arm” , "a wheel for his rump-bone” , and "a horse for his sprit” (ICS Zhuangzi 6/17/28-29) after his passing away. Zhuangzi' s view on the grand transformation of the myriad things has both a cosmological and an epistemological significance. The continuous transformation of the myriad things is of such a nature that it evades the possibility of comprehensive human understanding. Zhuangzi 5 says,

Death and life, preservation and ruin, failure and success, poverty and wealth, superiority and inferiority, blame and praise, hunger and thirst, cold and heat; these are the changes of circumstances, the operation of our appointed lot. Day and night, they succeed to one another before us, but our knowledge is not fully capable of discovering to what they owe their origination. (ICS Zhuangzi 5/15/1-2)

Similarly, Zhuangzi 6 says,

Mengsun knows nothing about why he lives and why he dies. He didn' $t$ know which came first, life or death, and which came last. He just went along with the transformation of things, awaiting the unknown transformation. Moreover, as we are about to undergo transformation, how do we know that we aren' $t$ already transformed? As we are about to cease transformation, how do we know that we have already transformed? (ICS Zhuangzi $6 / 19 / 1-3)$

Therefore, the essentials of existing things undergoing a "myriad transformations 萬化 (wan hua)" can perhaps be considered as an "evanescent fact" . Each transformation necessarily includes a state when "something 'is'”, and a subsequent state when "something 'is' not”, and a third state of indeterminacy that lies in between. In the Zhuangzi, this transformation reveals an inherent “oneness - (yi)" that is inherently shared by all. As Steven Coutinho remarked, "Things even 
become one another: a chrysalis becomes a butterfly; a seed becomes a tree. By dissolving boundaries, by turning dichotomies that separate things into penumbra that meld them, Zhuangzi turns our attention to the continuities, yi ( - — - that constitute the natural world as an interlocking web of cyclical processes" (Coutinho 2004, p. 68). The continuity of transforming individuals is sustained across time and space throughout all the formal changes of existing things.

How shall we, then, understand by what make this "oneness - (yi)" become possible? Let us consider the following passage from Zhuangzi 22:

For life is the follower of death, and death is the beginning of life; who can discern any fixed order to them? A birth of human is just a convergence of energy. When it converges, she lives. When it scatters, she dies. Since life and death follow each other, what is there to worry about? It is in this way that all things are one. People take what they consider beautiful to be sacred and wonderful and take what they dislike to be odious and rotten. But the odious and rotten transforms into the sacred and wonderful, and the sacred and wonderful transforms into the odious and rotten. Thus do I say, "Just open yourself into the single energy that is the world." It is for the sake of this that the sage values oneness. (ICS Zhuangzi 22/60/15-16)

One possible interpretive account of the continuity of "one" is that such that the myriad things are related by the identical underlying $q i$ (氣), of which they are constituted. Zhu Bokun argued that Zhuangzi' $\mathrm{s}$ view on life and death is fundamentally grounded by his belief in "the transformations of the myriad things shall ultimately return to the one $q i$... the birth and death of a person is but manifestations of the transforming $q i$, life ultimately has to return to its ancestral origin, i.e., the one qi” (Zhu 1994, pp. 20-21). Passages supporting this interpretation can be found in Zhuangzi 6: "they were being the fellow of the creator of things, wandering in the unity of the vital qi that joins heaven and earth" (ICS Zhuangzi 6/18/19) and "vital yin qi and yang qi were all out of kilter" (ICS Zhuangzi $6 / 17 / 26)$. In the outer and miscellaneous chapters, there are sayings such as, "I reflected on her beginning and realized that originally she was unborn. Not only was she unborn, she originally had no form. Not only did she have no form, she originally had no vital breath 氣 (qi). Intermingling with nebulousness and blurriness, a transformation occurred, and there was vital breath; the vital breath was transformed and there was form; the form was transformed and there was birth; now there has been another transformation and she is dead. This is like the progression of the four seasons-from spring to autumn, from winter to summer" (ICS Zhuangzi 18/48/11-12). Similarly, Zhuangzi 25 refers to the birth of the myriad things as, "The Yin-moon and Yang-sun reflected light on each other, covered each other, and governed each other; the four seasons replaced one another, generated one another, and ended one another. Likes and dislikes, go avoiding and moving towards, then arose; and from this came the separation and union of male and female. Then were seen safety and danger in mutual change; misery and happiness ensued from each other; leisure and urgency compelled each other; the aggregation and dispersion completed each other" (ICS Zhuangzi 25/76/17-18). What gives birth to the myriad things also brings the continuous transformation to all objects and undermines the possibility of rigid boundaries between all entities. Thus, the myriad things become an undifferentiated "one" in their unceasing, continuous transformative motion.

How then should we understand and live by the spontaneous self-so, the essential, and the authenticity of any particular individual among the myriad things? How can we possibly realize and 
maintain our authentic selves in such an inevitable grand movement? In between transformation and permanence, we can only find “lending 寄 (ji)” and “take up lodge 寓 (yu)” —a temporary lodging:

Make oneness your all dwelling places and let yourself be lodged in whichever cannot be avoided. Then you will be close to success. (ICS Zhuangzi 4/10/5)

When one is about to undergo his transformation, how does he know that it has not taken place? And when he is not about to undergo his transformation, how does he know that it has taken place? Take the case of me and you: are we in a dream from which we have not begun to awake? As for him (Mengsun), his physical form may meet with shocks, but this does not lose his mind. His life is to him but a morning' s lodging, so he does no real dying. (ICS Zhuangzi 6/19/3-4)

When a thing is brought into existence, it comes with certain faculties 才 (cai), nature 性 (xing), and ordinance 命 (ming). However, these characteristics are but part of the continuity of transformation to which all is subject. Therefore, only the “empty 虛 $(x u)$ ” and “vacate/none 無 $(w u)$ ” the mind, which can also be understood as “non-action 無為 (wuwei)”, can guarantee that a thing or a person can realize its/her authenticity in spontaneous self-transformation, even if only for a short moment in time. In the process of becoming oneself, one ought to "have no disturbance while passing through transformation 無怛化” (ICS Zhuangzi 6/18/2); have an attitude such that “the transformations of things are to him the ordinance for them, and he keeps fast hold of the origin of them 命物之 化，而守其宗” (ICS Zhuangzi 5/13/13); be capable of “sit-forgetting 坐忘 (zuowang)” in which one' s "connection with the body and its parts is dissolved; and perceptive organs are discarded. Leaving one' s material form, and bidding farewell to knowledge, thereby becoming one with the Great Thoroughfare 大通(datong)” (ICS Zhuangzi 6/19/20-21); keep “the fasting of the mind 心齋 (xinzhai)" to hold the pivot of the Dao 道樞 that transforms the myriad things, "when one rests in the displacement, and follows the transformation, then she enters into the formless heaven and in unity with it 安排而去化, 乃入於骞天一” (ICS Zhuangzi 6/19/6).

Lastly, the Zhuangzi describes or analogizes the experience of being one with the transformation of all things, including the experiencing subject. The boundary between what the subject is and what the subject is not is utterly dissolved. The identity of "I" ceases to have meaning: without "what I am”, there is nothing that I am not. On this sense, the myriad things and I are one:

Once Zhuang Zhou dreamed he was a butterfly, a butterfly flitting and fluttering around, happy with himself and conceiving that he was going to go anywhere he was willing to go. He followed his whims exactly as he liked and knew nothing about Zhuang Zhou. Suddenly he awoke, and there he was, Zhuang Zhou in rigor. He didn' $t$ know if he were Zhuang Zhou who had dreamed he was a butterfly or if a butterfly was now dreaming it was Zhuang Zhou. Zhou and the butterfly must count as two identities with necessary distinction. This is called the transformation of one thing into another (or, the Transformation of Things 物化 wuhua). (ICS Zhuangzi 2/7/21-23)

As an analogical story, the focal point of the butterfly dream in Zhuangzi 2 is not so much the two different life forms, but rather how the identity is maintained in the continuity of the flow. It conveys that the subject that passes through dreams is obviously not the "memory", the "shape" (as a butterfly or a person), nor the "capacity" of flying or thinking, but a transforming heart-mind 
at the very present "conceiving he is going to where he is willing to go", without knowing or not knowing what he is, or is not. In other words, Zhuangzi' s idea of an "authentic self" is that which sways between consciousness of the self and the paradoxical "none-self 無我 (wu wo)" which knows not what had been lost. From such a perspective, the boundary between one thing and another, or that between the subject and the other is a very unreliable foundation upon which essentials and fundamental natures are to be analyzed or explained. They are perhaps more like the shadow of the shadow, the penumbra - which is waiting for the unknown transition, always coming in and going out, being, and being-not, nearly absent but still there, a haunting translucency.

\section{Conclusive Remarks}

In opposition to theories that promote "becoming human" by cultivating universal, morally-charged "human essentials" , the Zhuangzi proposes a philosophical framework that is fundamentally grounded in an affirmation of the "myriad things" in connection with "heaven 天 (tian)”，“self-so/self-affirm 自然 (ziran)”，“essentials 情 (qing)”，“nature 性 (xing)”，“potency 德 (de)”, and “authenticity 真 (zhen)”. It deconstructs moral-essentialist theories which views "humans" as a unified whole with a universal morality and argues for a return to the respective essentials of innate and authentic nature and ordinance of the "myriad things", taking into full account of the possible meanings of life for all individuals as authentic existing lives. This standpoint of the Zhuangzi serves well to the advocation of "discard a classic image of humankind" (Rorty 1987, p. 313) by reflecting upon the post-World War II intellectual trend of treating humans as beings with an identifiable, common moral essence, instances of which include Platonist, Kantian, and empiricist thoughts. Akin to critiques offered by Jaques Derrida, Emmanuel Levinas, Gilles Deleuze, and Jean-Luc Nancy, etc., a grave danger looms behind the move to delimit human' s self-identity with any limited parameters that humans have come to exhibit. It risks the peril of formulating inaccurate definitions, distorting individual lives, and unjustifiably eliminating differences (May 1997).

The concept of "myriad things" is apt to preserve the individuality of "things" in their "myriad" variegated significance, against any possible homogenization of authentic individuals with essentialist reductions. It calls forth all existing entities that are distinct from one another and brings together the myriad things only under a collective name. It should also be noted that although the Zhuangzi places a particular emphasis on the "myriad things" and treats humans as members among many that are equal in stature, ${ }^{13}$ it is nonetheless a theory that first and foremost embraces the world of human beings. The "ultimate person 至人 (zhiren)" and the “authentic person 真人 (zhenren)" of the Zhuangzi represent ideal states of attainment only insofar as they are realizations of "self-so (ziran)" . In other words, the ultimate and most authentic realization of a "human" lies in the realization of herself as she is. Therefore, in a profound but paradoxical self-reflection, an authentic human being will not seek to "being as a 'human'” .

On the other hand, although mutually differentiated members of the myriad things are expressed with the concepts of “lone 獨 $(d u)$ ” and “self 自 (zi)” , the myriad things in Zhuangzi' s worldview are far from being unrelated objects with independent existence. The concepts of "oneness - (yi)" and "transformation 化 (hua)" interrelates all, forming mutually developing interconnections that

13 "When we would set forth the number of things (in existence), we speak of them as myriads; and human is only one of them 號物之數謂之萬, 人處一焉” (ICS Zhuangzi 17/43/30). 
make and transform one another. Besides the term “self-transformation 自化” from the Zhuangzi itself (ICS Zhuangzi 11/28/17; 17/45/11; 25/76/23), as Brook Ziporn' s insightful study on Guo Xiang' s philosophical interpretation, the great commentator connected the concepts of "lone 獨 $(d u)$ ” with “transformation 化 (hua)”, and brought out the compound concept “lone-transformation 獨化 (duhua)" . This composition shows an oxymoron, which also reveals the tension and complexity in Zhuangzi' s philosophy, for to transform is to become something other than self; however, the "lone 獨 $(d u)$ ” and “self 自 (zi)” preserves that one remains being oneself. While the self is becoming other, and becoming other, and becoming other, this constant flux and othering remains alone and identical (Ziporyn 2003, p. 100). The transformation of myriad things 萬物之化 (wanwu zhi hua) profoundly contains the self and the other, the all and the individuals. The "authenticity" of each individual entity among the myriad things are situated in a tumbling stream of dissolution and transformation with paradoxical upturns and downswings. From this perspective, the boundary between one thing and another is blurred. The boundary between the self and the external reality both is there and is not there. Our grasp on essentials are simultaneously upheld and undermined. More paradoxical, uncanny, and ungraspable than Laozi, who claims, “I alone am different from other people 我獨異於人” (Laozi 20) ${ }^{14}$, Zhuangzi instead proclaims, “I am one with myriad things 萬物與我為一” (ICS Zhuangzi 5/2/52-53). Therefore, in the final chapter of the Zhuangzi, it describes what Zhuangzi' s saying as such that “corresponding with transformation and emancipating from things 其應於化而解於物也” and as such of "principles are inexhaustible. The successor comes not from its predecessor. Vague! Ambiguous! Cannot get to the end of them 其理不竭, 其來不蛻, 芒乎昧乎, 未之盡者” (ICS Zhuangzi 33/100/11-12). For the Zhuangzi, there is no sound cause to be given that accounts for the stream of transformation of the myriad things and becoming our authentic selves shall be an ever-lasting, endless process.

Funding: This research received no external funding.

Conflicts of Interest: The author declares no conflict of interest.

\section{References}

Allan, Sarah. 1997. The Way of Water and Sprouts of Virtue. Albany: State University of New York Press.

Allan, Sarah. 2014. Shui Zhi Dao Yu De Zhi Duan-Zhongguo Zao Qi Si Xiang de Ben Yu (Zeng Ding Ban). (《水之道與德之端一中國早期思想的本喻》(增訂版) ). Translated by Haiyan Zhang 海晏張. Beijing: Shang Wu Yin Shu Guan.

Ames, Roger. 1989. Putting the Te back in Taoism. In Nature in Asian Traditions of Thought: Essays in Environmental Philosophy. Edited by J. Baird Callicot and Roger T. Ames. Albany: State University of New York Press.

Ames, Roger T., and David Hall. 2003. Daodejing: “Making This Life Significant” : A Philosophical Translation. New York: Ballantine.

Chan, Wing-Cheuk. 2005. On Heidegger' s Interpretation of Aristotle: A Chinese Perspective. Journal of Chinese Philosophy 32: 540. [CrossRef]

Chen, Guying. 2014. “Zhuangzi Lunqing: Wuqing, Renqing Yu Anqing”。 (莊子論情: 無情, 任情與安情). Zhe Xue Yan Jiu (《哲學研究》). 4: 50-59.

Chen, Xia. 2017. Dao Jia Zhe Xue Yin Lun. (《道家哲學引論》). Beijing: Zhongguo She Hui Ke Xue Chu Ban She.

Coutinho, Steve. 2004. Zhuangzi and Early Chinese Philosophy: Vagueness, Transformation and Paradox. Burlington: Ashgate Publishing Company.

Fang, Yong. 2012. Zhuang Zi Zuan Yao. (《莊子纂要》). Beijing: Xue Yuan Chu Ban She.

14 See (Lou 2008, p. 48). 
Graham, Angus C. 1986. How much of Chuang-tzu Did Chuang-tzu wright? Reprinted in Roth, Harold D. 2003. In A Companion to Angus C. Graham' s Chuang Tzu: The Inner Chapters. Honolulu: University of Hawai' i Press.

Graham, Angus C. 1989. The Book of Chuang-tzu and the problem of translation. In Chuang-tzu: The Inner Chapters. London: Unwin Hyman Limited.

Guo, Qingfan. 1997. Zhuang Zi Ji Shi. (《莊子集釋》). Taipei: Huazheng Shu ju.

Hansen, Chad. ; Translated by Kuang Zhao. 2013. Fojiao Chuanru Qian Zhongguo Sixiang Li De Qing. (佛教傳入 前中國思想裡的“情” ). Zhong Guo Ru Xue (《中國儒學》). , 257-285.

Hyun, Höchsmann, and Guorong Yang. 2007. Zhuangzi. New York: Pearson Longman.

Li, Pu. 2004. Gu Wen Zi Gu Lin. (古文字詁林). Shanghai: Shanghai Jiao Yu Chu Ban She.

Liu, Xiaogan. 2010. Zhuangzi's shilosophy and Its Transformation. Beijing: People's University of China Press.

Lou, Yulie. 2008. Laozi Dao De Jing Jiao Shi. (《老子道德經注校釋》). Beijing: Zhong Hua Shu Ju.

Mair, Victor H. 1994. Wandering on the Way: Early Taoist Tales and Parables of Chuang Tzu. New York: Bantam Books.

May, Todd. 1997. Reconsidering Difference: Nancy, Derrida, Levinas, Deleuze. Pennsylvania: The Pennsylvania State University Press.

McCraw, David. 2010. Stratifying Zhuangzi: Rhyme and Other Quantitative Evidence. Taipei: Institute of Linguistics, Academia Sinica.

Michael, Thomas. 2005. Pristine Dao, The: Metaphysics in Early Daoist Discourse. New York: State University of New York Press.

Michael, Thomas. 2015. In the Shadows of the Dao: Laozi, the Sage, and the Daodejing. New York: State University of New York Press.

Moeller, Hans-Georg. 2010. Dao De Jing De Zhe Xue. (《〈道德經〉的哲學》). Translated by Zengguang Liu. Beijing: Ren Min Chu Ban She, Originally published as 2006. The Philosophy of the Daodejing. New York: Columbia University Press.

Munro, Donald J. 1969. The Concept of Man in Early China. California: Stanford University Press.

Rorty, Richard. 1987. Zhe Xue Yu Zi Ran Zhi Jing. (《哲學與自然之鏡》). Translated by Li Youyan. Beijing: San Lian Shu Dian.

Schwartz, Benjamin. 1985. The World of Thought in Ancient China. Cambridge: Belknap Press of Harvard University Press.

Taylor, Charles. 1991. The Ethics of Authenticity. Cambridge: Harvard University Press.

The Institute for Excavated Documents of Peking University, and 北京大學出土文獻研究所編, eds. 2012. Beijing Da Xue Cang Xi Han Zhu Shu Vol. 2. (《北京大學藏西漢竹書〔貮]》). Shanghai: Shanghai Gu Ji Chu Ban She.

Wang, Bo. 2013. Zhuangzi Zhe Xue. (《莊子哲學》). Beijing: Beijing Da Xue Chu Ban She.

Wang, Zhongjiang. 2016. Order in Early Chinese Excavated Texts: Natural, Supernatural, and Legal Approaches. New York: Palgrave Macmillan.

Wang, Yubin. 2017. “De Xing Zhi Bian: Zhuangzi Nei Pian Bu Yan Xing Shi Yi” . “德”“性”之辨一《莊子》 篇不言 “性” 釋義). Zhe Xue Yan Jiu (《哲學研究》). 12: 65-73.

Wang, Bo. 2018. Ran yu Ziran de Xin Yan Jiu: Dao Jia Ziran Guan Nian de Zai Yan Jiu. ( “然” 與 “自然” : 道家 “自然”觀念的再研究). Philosophical Research (《哲学研究》). 10: 43-53+128-129.

Watson, Burton. 1968. The Complete Works of Chuang Tzu. New York: Columbia University Press.

Zhong, Tai. 1988. Zhuangzi Fa Wei. (《莊子發微》). Shanghai Guji Chubanshe: Shanghai: 上海古籍出版社.

Zhu, Bokun. 1994. Zhuang Xue Sheng Si Guan de Te Zheng ji qi Ying Xiang: Jian Lun Dao Jia Sheng Si Guan de Yan Bian Guo Cheng. (莊學生死觀的特徵及其影響—兼論道家生死觀的演變過程), Dao Jia Wen Hua Yan Jiu. Vol. 4 (《道家文化研究》第四輯). Dao Jia Wen Hua Yan JiuShanghai: Shanghai Gu Ji Chu Ban She.

Ziporyn, Brook. 2003. The Penumbra unbound: The neo-Taoist philosophy of Guo Xiang. Albany: State University of New York Press.

Ziporyn, Brook. 2009. Zhuangzi: The Essential Writings with Selections from Traditional Commentaries. Indianapolis: Hackett Pub. Co.

(c) 2019 by the author. Licensee MDPI, Basel, Switzerland. This article is an open access article distributed under the terms and conditions of the Creative Commons Attribution (CC BY) license (http://creativecommons.org/licenses/by/4.0/). 